\title{
https://doi.org/10.46813/2021-131-102 \\ CONTROL OF IONIZATION PROCESSES IN MAGNETRON SPUTTERING SYSTEM BY CHANGING MAGNETIC FIELD CONFIGURATION
}

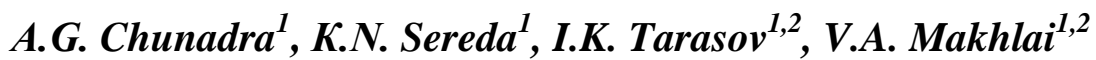 \\ ${ }^{I}$ V.N. Karazin Kharkiv National University, Kharkiv, Ukraine \\ ${ }^{2}$ Institute of Plasma Physics, National Science Center "Kharkov Institute of Physics and \\ Technology”, Kharkiv, Ukraine \\ E-mail: agchunadra@gmail.com
}

\begin{abstract}
This work is devoted to measuring the function of the distribution of charged particles of gas-discharge plasma in a magnetron sputtering system under conditions of non-potential "earth". Measurements are carried out with the help of a three-electrode probe, which is installed in the cathode sputtering zone, with unsafe electrodes and housing. The selection of the analyzed particles was carried out through a screen located under floating potential. Effect of additional magnetic insulation anode of MSS MAG-5 on ion and electron distribution functions was investigated.

PACS: $51.50 .+\mathrm{v}, 52.25 . \mathrm{Jm}$
\end{abstract}

\section{INTRODUCTION}

Present day trends of producing thin coatings with specified properties are based primarily on indicators of economic efficiency and productivity, as well as on the possibility of easy control and automation of production conditions. According to this, the most promising method is film deposition stimulated by plasma or socalled ion-plasma sputtering. Magnetron sputtering systems (MSS) occupy a special place among a wide class of devices for generating a flow of precipitated particles based on electrode erosion in a vacuum discharge Currently, they are becoming one of the main technological tools for obtaining thin coatings by spraying materials under ion bombardment. The efficiency of gas ionization has increased due to the use of crossed electric and magnetic fields in these systems. The plasma density has become tens of times greater than in magnetic-free devices with cathode (diode) sputtering. As a result, the ion current density on the cathode and the ion sputtering rate increased significantly. The working gas pressure was reduced. Many characteristics of the deposited layers were improved [1].

The works [2, 3] shown that application of additional magnetic insulation of anode leads to formation of anode magnetic trap for electrons of discharge. It's allows to increase efficiency of sputtering of target of MSS as well as rate of coatings deposition.

The information about the ions energy distributions is important for a better understanding of the effects accompanied ion bombardment during magnetron deposition of coatings in different deposition conditions.

The direct current magnetron discharge used in the magnetron sputtering device [4] is characterized by a reduced volume of discharge localization above the cathode surface. A large value 0.04...0.12 $T$ and strong homogeneity of magnetic field of arched configuration for both normal $150 \ldots 350 \mathrm{~T} / \mathrm{m}$ and tangencies directions are attributes of such systems. In this regard, the direct use of traditional diagnostic methods such as probe measurements is extremely difficult. For characterization of magnetron discharge structure by means of electric probe [5], the experiments are carried out using special magnetic systems with reduced value of magnetic field. Another way is investigation of discharge characteristics at relatively long distance from cathode i.e. in area of weak magnetic fields.

This paper presents the results of measuring the distribution functions of electrons and ions over energies in the zone of regular location of the treated surface. Measurements of the functions of the distribution of charged particles entering the processed samples from the discharge area were carried out by means a multi-grid energy analyzer with using a modernized technique based on the experimentally measured dependence of the cut-off current on the cutoff voltage.

\section{EXPERIMENTAL EQUIPMENT}

Experiments were carried out on a plant of type NNV-6.6-I1, modernized for the use of planar MSS of type MAG-5 with a tungsten target with a diameter of $110 \mathrm{~mm}$. Experiments were carried out both without the use of additional magnetic insulation of the anode, and under conditions of formation of an additional anode magnetic trap for electrons. For maximum localization of the discharge combustion area, none of the discharge system electrodes was grounded.

The working pressure in the chamber was set at $5 \cdot 10^{-3}$ Torr and provided by continuous uniform discharge of the working gas (argon) through the gas distribution system directly to the discharge area.

Under these conditions, a stationary magnetron discharge with parameters was ignited in the cathodeanode gap of the MSS $U_{p}=530 \mathrm{~V}$ and $I_{p}=0.5 \mathrm{~A}$. 
A capacitive type pulsed power supply unit with a thyristor switch provided a single voltage pulse of $3 \mathrm{~ms}$ duration and an amplitude up to $1.5 \mathrm{kV}$ to the cathodeanode gap. A single voltage pulse was applied between the cathode and the MSS anode against the background of a stationary magnetron discharge combustion voltage. The maximum discharge current at a highvoltage voltage pulse was $I_{i m p}=16 \mathrm{~A}$. The power supply of the energy analyzer, MSS and pulse unit was carried out through a distribution transformer, which provided reliable isolation along the power supply circuits and protection from parasitic signals.

During the experiments, the discharge current was measured by a current transformer (Rogovsky belt). Measurements of electron and ion energy distribution functions were carried out using a multi-grid energy analyzer (three-electrode probe), which was located directly above the cathode sputtering zone [6, 7]. Selection of the analysed particles was carried out through a screen located under floating potential. The functions of electron and ion energy distribution were calculated from the measured delay curves. The standard measurement technique is to ground one of the power supply terminals and the first grid of the energy analyzer. In our case, both the MSS electrodes and the three-electrode probe are not grounded due to design features.

Fig. 1 is a flowchart of the apparatus for studying the discharge parameters using a multi-grid analyzer. During the measurements, the limiting diaphragm, the first grid and the body of the energy analyzer were at floating potential. The distance from the magnetron to the limiting grid was $100 \mathrm{~mm}$. The diameter of the restriction diaphragm slot was $18 \mathrm{~mm}$. Voltage of $\pm(0 \ldots 150) V$ was fed to the grids 2,3 of the energy analyzer. Collector voltage is $\pm(0 \ldots 100) V$. Ion and electronic distribution functions were obtained by differentiating the volt-amperes characteristics of the collector.

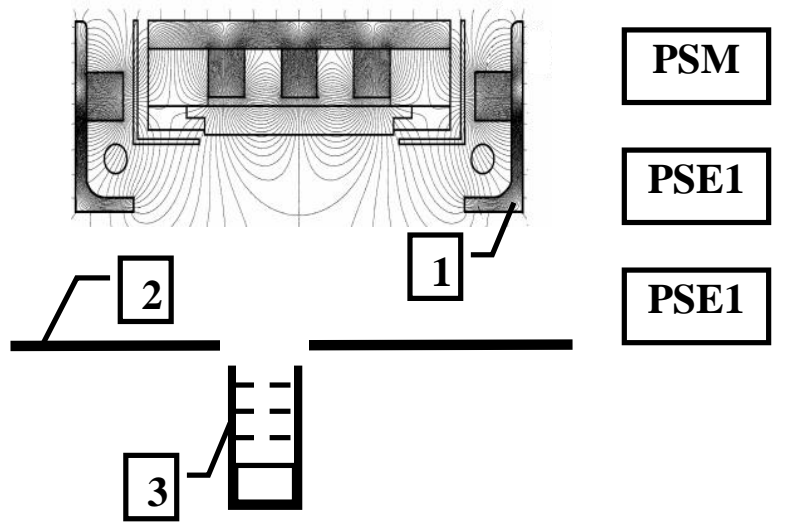

Fig. 1. Block-scheme of the installation for the study of discharge parameters using a multi-grid analyzer:

1 -MSS; 2 - bounding diaphragm; 3 - energy analyzer; PSM - magnetron power supply;

PSE1, 2 - energy analyzer power supplies

Some important points were taken into account when designing a multi-grid energy analyzer: a) the cell size of the input grid must not exceed two Debye radius $\left(r_{D}\right)$. This is necessary so that the internal potentials of the analyzer do not enter the external region where the plasma is located. In our case, the plasma density is about $10^{10} \ldots 10^{11} \mathrm{~cm}^{-3}$, then $r_{D} \approx 0.1 \ldots 0.3 \mathrm{~mm}$

$b)$ the design of the energy analyzer provided the possibility of its disassembly, replacement of individual elements and, if it is necessary, to change of the internal configuration;

c) mesh size of input grid $0.2 \mathrm{~mm}$, diameter of stainless wire $0.05 \mathrm{~mm}$. Collecting part is made in the form of cylinder with maximum external diameter of $25 \mathrm{~mm}$ and height in assembled form of $27 \mathrm{~mm}$.

\section{RESULTS OF EXPERIMENTS AND DISCUSSION}

Figs. 2, 3 show the distribution functions of electrons and ions at different values of the cut-off potential applied to the networks 2 and 3 of the multiset probe.

It was expected that electron and ion distribution functions would have one maximum under the standard MSS configuration without additional anode magnetization. The presence of one maximum on the distribution functions was assumed due to the formation of one ionization zone in the cathode-anode gap, due to the existence of a standard azimuth symmetric arched magnetic trap over the target cathode.
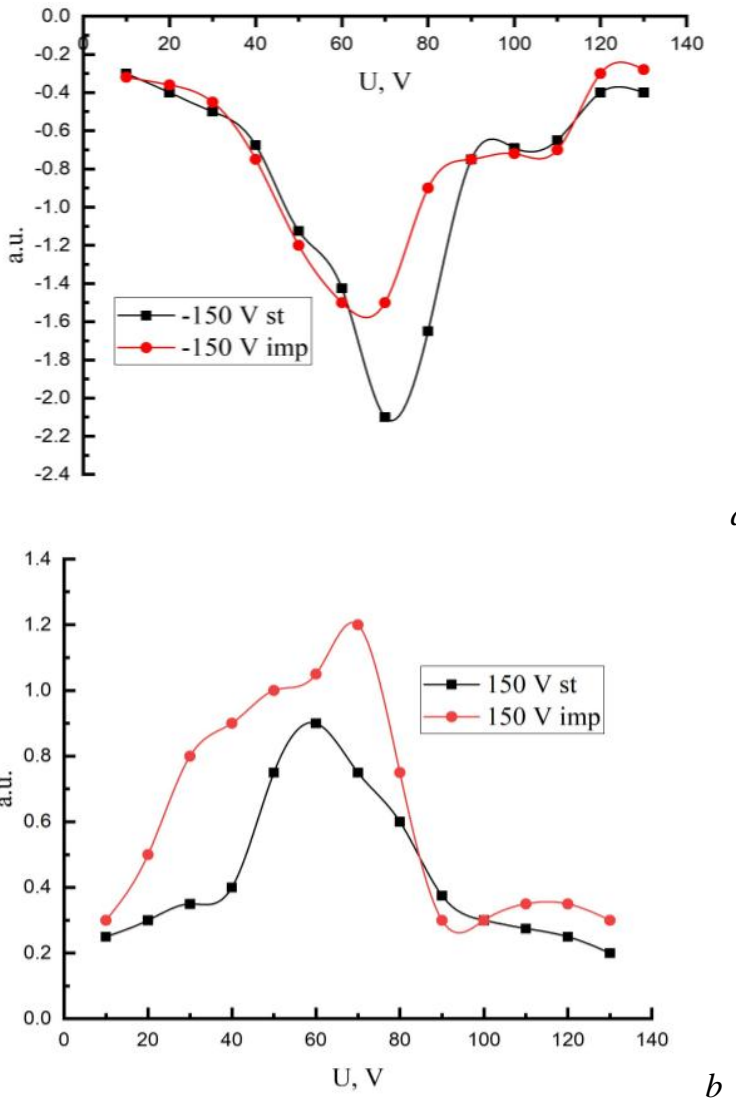

Fig. 2. Electron (a) and ion (b) component of the MSS distribution function without additional magnetic insulation of the anode. Black line corresponds to the stationary discharge, red-pulsed 
The use of additional magnetic insulation of the anode with the formation of an anode magnetic trap for electrons should lead to the appearance of another maximum on the distribution functions of electrons and ions due to the formation of an additional anode ionization zone.

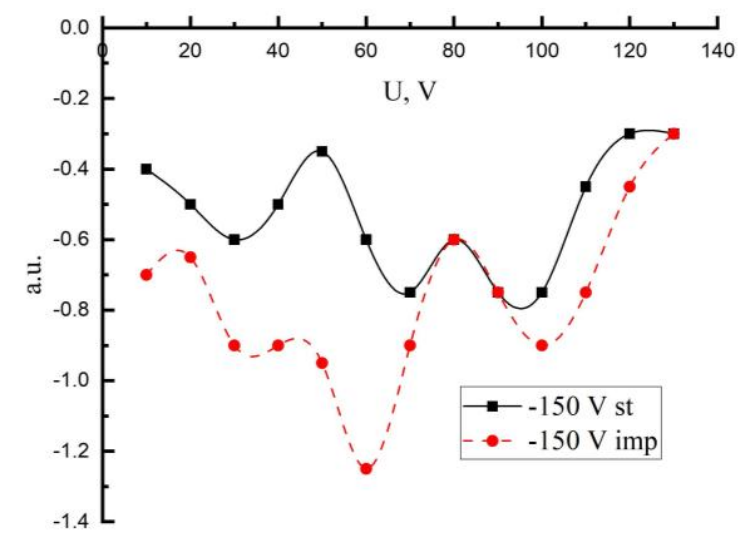

$a$

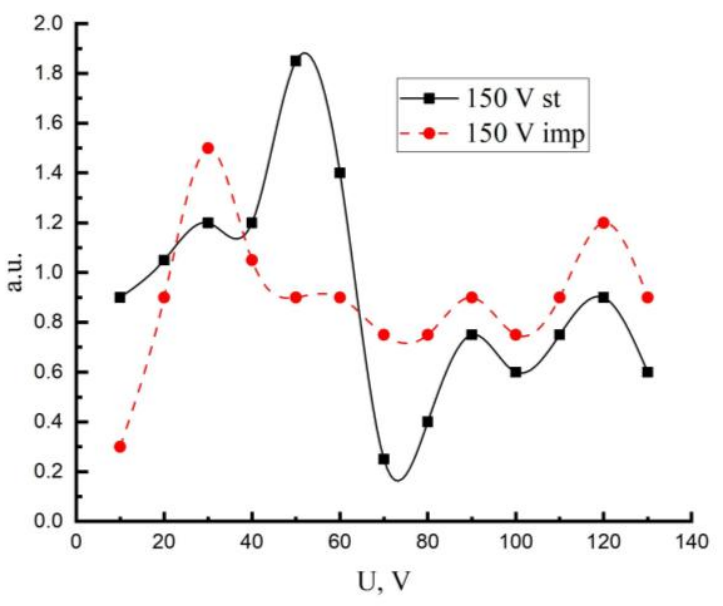

$b$

Fig. 3. Electron (a) and ion (b) components of the MSS distribution function in case of additional magnetic insulation of the anode. Black line corresponds to the stationary discharge, red-pulsed

Under the conditions of the pulsed mode of operation of the MSS, it was expected that the maximum on the functions of the distribution of charged particles would shift to the region of higher energies due to the addition voltage.

However, as can be seen from Fig. 2, even under the standard MSS configuration without an additional anode magnetic trap, the presence of two maximums is supposed on the electron and ion distribution functions. But it is not very clearly recognized.

This type of energy distribution functions (with multi-maximums) of charged particles in the MSS allows us to conclude that the distribution of potential drop in the interelectrode space of the MSS is significantly non-monotonic. Each of the maximums on the electron distribution function corresponds to a group of electrons that are accelerated by an electric field in the spatial layers of the potential drop in the interelectrode space of the MSS.
Two maximums are also recognized in the ion distribution function (especially clearly in the pulsed mode of operation). The energy of the ion is determined by the place of its birth in the discharge interval and the difference in potentials that it passes after the act of ionization. Therefore, the presence of several maximums on the ion distribution function indicates the formation of several spatially spaced ionization zones in the discharge interval.

Such result can be explained either by additional ionization on peripheral area outside MSS due to unbalance of magnetic configuration, or by formation of extended ionization zone, which is characteristic for discharges in crossed electric and magnetic fields [4].

The use of additional magnetic insulation of the anode ensures the complete elimination of unbalance of the magnetic system MSS on the peripheral area and the formation of the optimal configuration of the anode magnetic trap [4].

The function of electron energy distribution under conditions of additional magnetic insulation of the anode (see Fig. 3,a) shows three clearly expressed maximums. The appearing of these maximums can be explained by the feature of the potential drop distribution in the MSS interelectrode space. One maximum is formed due to ionization in the main zone of magnetron discharge within an arched magnetic trap above the target cathode of the MSS. The second appeared due to the formation of an extended ionization zone. The third forms in an additional anode magnetic trap, where conditions are created for the occurrence of an additional non-independent discharge of magnetron type.

The function of ion distribution over energies is unexpected at the conditions of using additional magnetic insulation of the anode (see Fig. 3,b). The four maximums are clearly traced. The presence of such maxima on the ion distribution function indicates the formation of four spatially spaced specific zones in the discharge interval.

The existence of three maximums can also be explained by the formation of three ionization zones. Those form in the main arch magnetic trap of the MSS, in the additional anode magnetic trap and in the extended ionization zone. It is same as for functions of the distribution of electron. Nevertheless, the presence of the fourth maximum on the ion function of distribution indicates the formation of additional ionization zone in the discharge and requires further careful research.

In addition, it was expected a shift of maximum on the functions of the distribution of charged particles to the region of higher energies due to the additional potential at the conditions of the pulsed mode of operation of the MSS. However, it is not identified from received experimental results clearly. Therefore, this effect should be studied in future experiments

Nevertheless, in generally, the ionization processes determine the value of density in the discharge plasma, the formation of additional ionization zones contributes as well as to the intensification of the discharge. The both electron and ion currents are growth as result of an increase of the charged particles number in the plasma. 
Thus, the presence of additional ionization should significantly increase the efficiency and speed of the spraying process due to increasing of amount of sputtered material from the target-cathode by ion flow in MSS.

\section{CONCLUSIONS}

The energy distribution functions have been measured for electrons and ions emitted from the discharge and delivered to processed samples in magnetron sputtering systems.

It has been shown that the use of additional magnetic insulation of the anode causes the formation of an anode magnetic trap for electrons. It's leads to the appearance of at least two maximums on the distribution functions of electrons and ions due to the formation of an additional anode ionization zone.

\section{REFERENCES}

1. B.S. Danilin. Low temperature plasma application for thin films deposition. M.: "Energoatomizdat", 1989. 2. A.A. Bizyukov, K.N. Sereda, V.V. Sleptsov, I.K. Tarasov, A.G. Chunadra. High-current pulsed operation modes of the planar mss with magnetically insulated anode without transition to the arc discharge // Problems of Atomic Science and Technology. Series “Plasma Physics” (18). 2012, № 6 (82), p. 190-192.

3. A.G. Chunadra, K.N. Sereda, I.K. Tarasov, A.A. Bizyukov. Increasing of mass transfer efficiency at magnetron deposition of metal coating // Problems of Atomic Science and Technology. Series "Plasma Physics” (21). 2015, № 1 (95), p. 181-183.

4. A.I. Kuzmichov. Magnetron sputtering system. Kiev: "Avers", 2008 (in Russian).

5. R. Huddlestone, S. Leonard. Diagnostics of plasma. M.: "Mir", 1967, p. 515.

6. A.G. Chunadra, K.N. Sereda, I.K. Tarasov. Method for measuring external and internal parameters of plasma with ungrounded gas discharge electrodes // Problems of Atomic Science and Technology. Series "Plasma Physics". 2019, № 1, p. 219-221.

7. I.N. Sereda, A.F. Tseluyko. Probe methods of plasma diagnostics: for undergraduate and postgraduate students studying plasma diagnostics / V.N. Karazin Kharkiv National University, 2015, 189 p.

\title{
УПРАВЛЕНИЕ ПРОЦЕССАМИ ИОНИЗАЦИИ В МАГНЕТРОННОЙ РАСПЫЛИТЕЛЬНОЙ СИСТЕМЕ СМЕНОЙ КОНФИГУРАЦИЙ МАГНИТНОГО ПОЛЯ
}

\author{
А.Г. Чунадра, К.Н. Середа, И.К. Тарасов, В.А. Махлай
}

Работа посвящена измерению функции распределения заряженных частиц газоразрядной плазмы в магнетронной распылительной системе в условиях непотенциальной «земли». Измерения проведены с помощью триэлектродного зонда, расположенного в зоне катодного распыления, с незаземленными электродами и корпусом. Отбор исследуемых частиц проводили через экран, находящийся под плавающим потенциалом. Исследовано влияние дополнительной магнитоизоляции анода МРС МАГ-5 на функции распределения ионов и электронов.

\section{КЕРУВАННЯ ПРОЦЕСАМИ ІОНІЗАЦІЇ В МАГНЕТРОННІЙ РОЗПОРОШУВАЛЬНІЙ СИСТЕМІ ЗМІНОЮ КОНФІГУРАЦІЙ МАГНІТНОГО ПОЛЯ}

\section{А.Г. Чунадра, К.Н. Середа, І.К. Тарасов, В.О. Махлай}

Робота присвячена вимірюванню функції розподілу заряджених частинок газорозрядної плазми в магнетронній розпорошувальній системі в умовах непотенційної «землі». Вимірювання проведені за допомогою триелектродного зонду, який встановлено в зоні катодного розпилення, 3 незаземленими електродами i корпусом. Відбір досліджуваних частинок проводили через екран, розташований під плаваючим потенціалом. Досліджено вплив додаткової магнітоізоляції анода МРС МАГ-5 на функції розподілу іонів та електронів. 